\title{
Lifelong Learning at Universities: Future Perspectives for Teaching and Learning
}

\author{
Eva Cendon* \\ Department of University Continuing Education \& Teaching and Learning, FernUniversität in Hagen (Hagen \\ University), Germany \{eva.cendon@fernuni-hagen.de\}
}

Received on 17 May 2018; revised on 22 May 2018; accepted on 18 June 2018; published on 15 July 2018

DOI: $10.7821 /$ naer.2018.7.320

(c)) BY-NC-ND

\begin{abstract}
This paper examines practices of teaching and learning in the era of digitalization. More specifically, it addresses practices of teaching and learning for students with professional experience who work alongside their studies. Based on the assumption that digitalization is a means of allowing more open and flexible pathways for teaching and learning in higher education, the paper focusses on the perspectives and perceptions of both students and teachers in digital supported teaching and learning environments as forms of blended learning. It brings together findings from two qualitative empirical studies: one focused on students' perspectives of their development over the course of their studies; the second addressed teachers' perspectives and their teaching strategies and activities. Based on the findings of these two research studies, the paper outlines future perspectives for teaching and learning and the role of digitalization, with a particular emphasis on programs of lifelong learning at universities.
\end{abstract}

KEYWORDS: ACTIVE LEARNING, LEARNING PROCESSES, STUDENT PARTICIPATION, TEACHING STYLES, TEACHING METHODS.

\section{INTRODUCTION}

The all-encompassing idea of lifelong learning has certainly altered understandings of education in different contexts, putting increased focus on the quality of teaching and learning at universities. Lifelong learning shifts the focus from an institutional view to the learner and his or her learning, which includes life-long, life-wide, and non-formal and informal learning processes. It stems from the premise that individuals need to update and enhance their skills and competencies throughout their lives and therefore re-enter educational processes in various phases of their (working) lives. For higher education institutions, this means a shift from the traditional role of educating young students coming directly from school to navigating a wide range of students re-entering higher education at different phases of their lives. Within the paradigm of lifelong learning, learners are at the forefront: more specifically, they all have varying backgrounds and learning paths that bring them (back) to universities as lifelong learners. (Schuetze, 2014; Schuetze \& Slowey, 2012). Universities need to respond

*To whom correspondence should be addressed: FernUniversität in Hagen, Lehrgebiet Wissenschaftliche Weiterbildung und Hochschuldidaktik, Universitätsstraße 27, 58097 Hagen more flexibly to individual learners' needs and changing market requirements. This manifests in multiple ways in terms of program differentiation, from research to professional degrees, modules, certificates that may lead to bachelor's or master's programs, and stackable credentials that allow students to leave higher education and return later, with their credits counting toward the next certificate or degree. Programs vary in their modes of delivery, providing options for part-time or full-time study, aligning work and study in work-integrated or work-accompanying programs.

Digital technologies have supported teaching and learning by enabling different modes of delivery. These range from classroom-based teaching using digital technologies as teaching and learning aids to online learning where the entire teaching and learning process takes place via digital technology. Somewhere in the middle are the different types of blended teaching and learning where digital resources play a prominent role (Bates, 2015). Whereas the different modes of delivery support students' learning according to their geographic locations, learning styles and time constraints, the respective pedagogy allows digital technologies to unleash their full potential for teaching and learning. With an emphasis on the diversity of students as lifelong learners, constructivist approaches and student-centered learning have become policy-led core priorities redefining the respective roles of teachers in higher education (Attard, Di Ioio, Geven, \& Santa, 2010; Redecker et al., 2011; Sursock, 2015).

Digital technologies are a means to enhancing teaching and learning flexibility, and hence provide new possibilities of where and when to learn and to teach. Willcox, Sarma \& Lippel (2016), in their paper exploring the possibilities of online education, see digital technologies as "an enabler by providing a dynamic digital scaffold" (Willcox et al., 2016, p. x). Nonetheless, as several authors point at (amongst others Ryberg, 2013), digital technologies do not automatically improve teaching and learning processes. They can be used as merely up- and download repositories, allowing one-way communication between teachers and students, but not altering the quality of teaching and learning processes with regard to more student-centered teaching and learning. Moreover, through distance as well as different tools and multiple choices of media, guidance and interaction becomes even more relevant. (Akbar, 2016) As such, teachers in digital learning environments have an important role: Supported by technologies, they get space and time to provide context and to act as mentors and foster reflection and discussion by having high-value interactions with students (Willcox et al., 2016). 
This places the focus on the relationship between the teacher and the learner. Over 40 years ago, Knowles (1975) outlined what it means for teachers to support students and hence become a facilitator of their self-directed learning. In the 1990 s, research was done on approaches to teaching in higher education, linking it to students' approaches to learning with reference to Knowles' findings (Marton, Beaty, \& Dall'Alba, 1993; Trigwell, Prosser, \& Waterhouse, 1999). A meta-analysis of interview-based investigations on conceptions of teaching (Kember, 1997) shows more similarities: The teacher-content-oriented conception and the student- learning-oriented conception form the poles of a continuum of five dimensions of conceptions of teaching: Teaching as (1) imparting information, (2) transmitting structured knowledge, (3) interaction between the teacher and the student, (4) facilitating understanding on the part of the student, and finally (5) bringing about conceptual change and intellectual development in the student. In each conception teachers act in different roles: from presenters of knowledge ( 1 and 2) to tutors, inviting students to actively participate in an interactive process (3) to facilitators of the students' learning processes (4) and as change agents or developers supporting the development and the (changing) conceptions of students (5). Interestingly, the role of teachers as developers and change agents occurred in postgraduate teaching only (Kember, 1997).

Table 1. Conceptions of Teaching (Kember, 1997)

\begin{tabular}{lllll}
\hline (1) & $(2)$ & $(3)$ & $(4)$ & $(5)$ \\
imparting & $\begin{array}{l}\text { transmitting } \\
\text { information } \\
\text { structured } \\
\text { knowledge }\end{array}$ & $\begin{array}{l}\text { teacher- } \\
\text { student } \\
\text { interaction }\end{array}$ & $\begin{array}{l}\text { facilitating } \\
\text { understanding }\end{array}$ & $\begin{array}{l}\text { conceptual } \\
\text { change }\end{array}$ \\
\hline presenter & presenter & tutor & facilitator & $\begin{array}{l}\text { change } \\
\text { agent and } \\
\text { developer }\end{array}$ \\
\hline
\end{tabular}

Kember's systematization is still used for conceptualizing roles of teachers in higher education (Entwistle, 2009; Roberts, 2004). Recently, Cutajar (2016) investigated students' perceptions of considering teachers as contributors to their learning yet assigning them roles. Her research shows how important it is to link the perspectives of both teachers and students when investigating teaching and learning practices. This is of even more relevance as relationships between students and teachers and their assigned roles in higher education change; new concepts of networked learning supported through digital technologies and the diversity of students as lifelong learners lead to the shifting of hitherto clear boundaries between students and teachers (Beaty \& Howard, 2010).

Thus, the aim of this paper is to shed light on teaching and learning practices in higher education, with special emphasis on university continuing education study programs. Up until now, there has been a paucity of research on teaching and learning practices in lifelong learning programs (at least in the German context). This paper will focus, on the one hand, on the perspective of (lifelong) learners, as based on a longitudinal qualitative study at a German university for professional studies, and on the other hand, on the perspective of teachers and their teaching in such programs, as based on an explorative qualitative study on teachers in higher education. In the following, the results of two research studies are presented and then compared to each other. Subsequently, the perspectives for teaching and learning are outlined - with a particular emphasis on boundary issues. The paper concludes with outlining different routes for teaching and learning.

\section{CONTEXT AND METHODS}

This paper brings together the results of two explorative research studies in the context of teaching and learning in job-accompanying study programs delivered in a blended learning mode. Both research studies were conducted in the field of university continuing education or professional studies and were of an exploratory nature, as thus far there has been little research done in this field. One study focused on the perspective of students as professionally experienced learners, studying part time in job-accompanying master's programs in a blended learning model at the same German university specialized in professional studies. (Cendon, 2016, 2017) The other research focused on the perspective of experienced teachers in higher education and their teaching with adult learners in professional studies. (Cendon, Mörth, \& Schiller, 2016) Hence, both studies form the two sides of teaching and learning practices. The studies were done separately and followed a different methodology.

\subsection{Student perspectives on learning: context, sample and methodology}

The research study on the perspectives of students was conceptualized as an explorative, qualitative longitudinal research (2012-2015), accompanying students during their course of studies. The sample consisted of all students of four master's programs - all in all 26 students, 17 women and 9 men ranging in age from 25 to 55 years at the beginning of their studies. Most of them had a first academic degree and at least two years of professional experience, with some students having almost 30 years of professional experience. Their academic and professional backgrounds varied widely. Half of the students had also completed vocational education, including six students without a first academic degree. The students were studying in four interdisciplinary job-accompanying master's programs, in the fields of education, health, and economics and management. As a compulsory component of their studies, all students were required to meet in joint study modules focusing on management skills (Cendon, in press). All study programs followed the same blended learning study model as a form of hybrid learning (Bates, 2015). The model had been organized as a structured rotation model with alternating distance learning (study booklets printed and as e-books), online modules with a duration of several weeks (with asynchronous and synchronous e-learning), face-to-face-seminars (quarterly) as well as a oneweek in person component, a so called 'field trip,' after one year of studying (Cendon, in press). Material for the analysis comprised the students' letters of motivation (written before enrolment), two group discussions with all students (after six months of study and after one year of studies) and guided interviews with four students after the end of their studies. The guiding research question was how students perceive their development and their reflection at different points during the course of their studies. The data was analyzed using qualitative content analysis following predefined theoretically based categories (Mayring, 2000). Whereas results of the study have already been published with a focus on reflection and reflective learning (Cendon, 2016, 2017) - the primary interest in this paper lies in the students' development over the course of their studies.

\subsection{The teachers' perspective on teaching: context, sample and methodology}

The research study on the teachers' perspective on teaching was a qualitative explorative research study with experienced teachers in higher education who teach in professional studies, thus wor- 
king with students who have professional experience (Cendon, Mörth, \& Schiller, 2016). The aim of the study was to conceptualize the teachers' roles from their perspectives within university continuing education, dealing with professionally experienced students. From March 2013 to June 2015, seven guideline-based expert interviews were conducted with nationally and internationally active teachers in higher education from Germany, Austria, Canada, and the Netherlands. All interview partners had long-standing teaching experience in continuing education within higher education and outside higher education in professional and corporate contexts, including online and face-to-face teaching. Four interview partners were university professors, and three worked as trainers and consultants. Five of the interview partners were teaching in job-accompanying master's programs at the same university specialized in professional studies, and two taught in similar programs at other universities. The analysis followed grounded theory methodology using "a systematic set of procedures to develop an inductively derived grounded theory about a phenomenon" (Strauss \& Corbin, 1990, p. 24).

\section{RESULTS}

In this section, the central results of both research studies are presented.

\subsection{Development over the course of studies}

In the research study on the students' perspective the analysis of the data followed three categories as foci of development and reflection: knowledge, (learning) strategies, and the own person as professional or as researcher (Zuber-Skerritt \& Cendon, 2014).

\subsubsection{Arriving and first changes}

"And through studying I needed to learn how to read something calmly. [...] I had to come to terms with reading the study material leisurely and purposefully." (GD1_MBA, 25 [I9])

A central aspect in the transition from the professional world to academia and studies was the arrival as student. Hence, learning strategies were the dominant focus of reflection, particularly in the first group discussion. Students struggled with organizing their studies and integrating it into work and private life, and with their own work-life-study balance. Some had already developed initial coping strategies, such as working to scale down personal expectations, trying to be disciplined when studying, and adopting learning strategies from fellow students. The first months were also important for students to get to know their learning type and to develop (new) learning strategies. Students reported setting up learning groups in tandems as a learning strategy - both in weekly face-to-face sessions and in regular Skype and telephone sessions. Although their start as students may have been confusing, over time, the students observed that they were able to discern structures in their professional practice that they were not aware of before. This realization of things that go wrong in the professional context also led to discontent or even frustration for some students, in terms of not (yet) being in a position to change them or not feeling heard within the organization. Reflecting on their experiences over the first six months of their studies, students noted that they were looking for and finding connections between knowledge attained during studies and their professional practice. They reported that they were able to transfer pieces of knowledge into their practice and integrate topics from their practice into studies, offering a new frame of reference. With regard to their own development as persons during the first months, the (new) self-perception as students both in the academic and professional environment was central - both for themselves and for their private and professional surrounding.

\subsubsection{Observing and trying to understand}

"I have a greater perspective. And I do not have the feeling that I know less, but rather that I know more, but I am still organizing all of this." (GD2_BKM, 17 [I19])

After one year of study, students became more cautious concerning the acquisition of knowledge and its direct transfer into their practice. Some students described a growing awareness of gaps, things they do not know, and their own limitations that irritated them and slowed their performance. At the same time, they perceived acquired knowledge as helping them to understand and assess structure and culture within the organization, as a means by which to take a step back, see things more clearly, and understand existing problems better. Students not only took a more critical look at themselves, but also at colleagues and superiors and their behavior within the organizational context. They described more active observing, stepping outside of situations, taking a bird's eye perspective, taking more time to think, and pondering before acting, but also increased self-esteem and self-consciousness. With regard to their role as students, they became more conscious of their learning strategies. They reported more efficiency and a better ability to prioritize. Students discovered their ideal places to study (e.g., in the office after work), could better distinguish between study and leisure time, and were mostly able to accept and deal with their learning rhythms and learning styles, and they worked in their established learning groups.

\subsubsection{Positioning and self-assurance}

"I have become calmer and settled, as I know now what I can do. However, I also know what I cannot do, and this is very important”. (I5, 36)

In retrospection to their studies, the interviewed students formulated that they have learned to explore and acquire new knowledge autonomously through their studies (not least through writing their master's thesis). They were also able to translate this ability into their professional practice. Furthermore, the studies had contributed to their strategic acting in their professional fields and they reported feeling confident to explore new avenues.

Fellow students were perceived as central counterparts in the social exchange and with regard to exchange of knowledge. On the one hand, they were the ones who provided stability, support and positive feedback over the course of studies; on the other hand, because of their knowledge and expertise in different professional fields, fellow students facilitated interactive learning and new perspective taking opportunities in one's own professional field and practice.

Teachers were perceived as important for students' own development. The variety of teachers and their different approaches and teaching styles was helpful depending on one's needs. In particular, teachers were important for providing encouraging and critical feedback and as role models from whom students could learn. Students identified teachers in retrospect as supportive partners in the learning processes.

Three overall findings are relevant for the assessment of the results of the study. Firstly, over the course of the studies acquiring knowledge became less relevant in students' statements. Instead, engagement with one's own personality, professional relationships with others, and heightened ability to examine one's own 
professional organizational context became increasingly relevant. Thirdly, the importance of counterparts for reflection and development both within the study (teachers, and more prominently fellow students) and professional context (colleagues and superiors) was identified as being critical in supporting students' development with regard to knowledge, processes and as individuals.

\subsection{Teaching strategies and teaching activities}

In the study on teachers' perspectives, one teaching strategy predominated in the analyzed data: that of 'drawing on experiences' to which all other strategies relate. Thus, 'drawing on experiences' is the phenomenon in the paradigm model. Teachers follow different teaching strategies to relate to the phenomenon of 'drawing on experiences': (1) creating an atmosphere for learning; (2) presenting knowledge; (3) stimulating learning from each other; (4) opening up for new approaches; (5) stimulating reflection. The first and the last of these learning strategies hold a special position, as they are also preconditions for the success of drawing on experiences. The five teaching strategies cannot be seen as discrete or independent entities, as some are closely connected and are consciously combined within the concrete teaching practice. Depending on the teaching strategy, different teaching activities are deployed.

The causal condition for teachers drawing on experiences in their teaching are the students and their myriad professional and life experiences who are returning to university for university continuing education. The context in which the phenomenon manifests are job-accompanying study programs and modules at higher education institutions. Different teaching strategies aim at drawing on experiences via concrete teaching activities, and entail particular consequences. Intervening conditions are factors that have restricting or promoting effects on the phenomenon: individual framework conditions like the willingness and openness of teachers and students to draw on experiences, or organizational framework conditions, such as the spatial and temporal structure of the teaching-learning situations.

\subsubsection{Creating an atmosphere for learning}

“...it is important to create an atmosphere; well, humor is also important, I think; also to treat each other with respect, so that one says: 'Yes, I can get involved with the others.' Meaning, one has to create a feeling of trust." $(\mathrm{T} 5,45)$.

Establishing an atmosphere for learning has a special position within the learning strategies. Creating a convenient environment and an open atmosphere between students and between students and teachers is a precondition for drawing on experiences. Hence, the atmosphere for learning is crucial for the success of the other teaching strategies. A central teaching activity within this strategy is creating trust, as it is a precondition for exchange. Teachers create an environment that allows students to get involved (with others) and to contribute and share their experiences. Teaching activities that add to an atmosphere for learning include providing space for students' experiences and contributions, and appreciating their different realities and contributions. As a result of these teaching activities, teachers hope that students open up, share their experiences, listen closely to the others' experiences, and begin a mutual exchange with their fellow students and with the teacher.

\subsubsection{Presenting knowledge}

"If there is something new, they [the students] need to get exposed to it, also here [at the university]. [...] But this is not enough!" (T3, 31)

Presenting knowledge as a teaching strategy is intended to facilitate students' actual knowledge and provide theoretical stimulation. Teachers present knowledge and try to create interfaces for the students' experiences by inviting them to get involved. They do so by putting up knowledge for discussion, exposing it to student review based on their professional practice/experiences and by asking questions that should encourage students to relate the knowledge to their experiences from practice. Consequently, students should be able to relate their own practice to theory and, based on that, find new ways of dealing with their professional practice and develop it further.

\subsubsection{Stimulating learning from each other}

"So, they are coming from different angles and both angles are incomplete in and of themselves. [...] when it is possible to have practitioners and young students together that is ideal. I put them in teams." $(\mathrm{T} 2,60)$

\section{Categories of the model}

Students with professional and real-world experiences

\section{DRAWING ON EXPERIENCES}

University continuing education/Professional studies
Instructing

Moderating

Inquiring

Providing feedback

Advising

spatial and temporal structure of teaching learning-situations

\section{Position of the categories}

\author{
Causal conditions \\ Phenomenon \\ Context \\ Teaching strategies \\ and teaching activities \\ Intervening conditions
}

teachers and students to relate to experiences

Figure 1. The paradigm model 'drawing on experiences' 
Learning from each other as teaching strategy places the experiences of the students at the forefront. Teachers provide space for a mutual exchange of experiences and enable learning from each other by stimulating it. Their teaching activities entail initiating this exchange, guiding it in both structured and less structured ways, and if necessary, moderating it. Teachers support exchange either between more or less professionally experienced students or between students with different academic and/or professional backgrounds. Ideally, this leads to increased engagement and mutual exchange between students based on their distinct experiences, enriching the learning experience.

\subsubsection{Opening up for new approaches}

“...there are types of people who do not allow themselves to get challenged, who expect that this [what he or she learns] is confirmed in his/her practice. And if it is not confirmed in practice, it - unfortunately - is a poor and too theoretical continuing educational training. And of course, this [view] is not acceptable because this [training] lives from the confrontation between theory and practice and ... I think... sometimes ... yes, one has to endure that it can't be understood at this very moment, but its value will unfold [later].” (T5, 37)

In this teaching strategy, students' experiences are the starting point for learning and development insofar as they are called into question. Only when students are able to question their prevailing assumptions, only if they are willing to 'unlearn,' will they be able to open up for new approaches, to further develop and advance their own professional practice. Teaching activities include confrontations, e.g. through challenging theories or content that conflict with or question the students' experiences. The activities evoke interest for new approaches even if they cannot be immediately translated into students' practice. Teachers initiate confrontations but also facilitate them in group processes, in which students should deliberately challenge themselves mutually via their different viewpoints on specific topics. As a result, students broaden their views and thereby find new theories and approaches that enrich their professional practice and offer them new perspectives.

\subsubsection{Stimulating reflection}

"But, the decisive factor is that one does not take one's own routines for granted. Having said that it takes me directly to the keyword for reflection: Question the obvious. And that's what I need to teach the students." (T3, 155)

The aim of this teaching strategy is that students widen their perspective and thus critically examine their basic assumptions. Here, the relation to the other teaching strategies becomes particularly obvious as 'to stimulate reflection' is an integral component of the strategies 'presenting knowledge', 'learning from each other' and 'opening up for new approaches'. Students should engage in self-reflection and reflect on group processes, theoretical knowledge, and their professional practice in a systematic way, both individually and collectively. Self-reflexivity and structural reflexivity are explicit aims identified by the interviewed teachers. Reflection is stimulated from two sides: as originating from theoretical knowledge or from professional or real-world practice. An important teaching activity is asking questions that stimulate reflection. By systematically asking questions, teachers try to stimulate students' reflection on their practice, its constraints and its possibilities. Another activity entails working with case studies: fictional but authentic case studies or case studies from the practice of the students (so called "living cases") elaborated upon either individually or collaboratively. Teachers support the process by asking critical questions and hence stimulate critical assessment and critical thinking. Intended consequences of this strategy are that students acquire the ability for self-leadership, developing a mature self-reflective personality. They should be able to recognize their scopes and courses of action as well as successfully deal with the organizational framework conditions in the sense of a structural reflexivity. This strategy shows the relevance of the dimension of time. On the one hand, time en bloc (i.e. trough block seminars instead of two hours a week) is needed to guide instruction; on the other hand, a longer period of time is necessary so that students can engage with a topic in depth from different perspectives or with their own personal development.

\section{DISCUSSION}

In linking the results of the two research studies, some limitations need to be mentioned. First, both studies are of an exploratory nature and therefore limited in their scope. In addition, the studies used different methodologies and methods of analysis. Whereas the first is looking at development, the second is based on strategies that are deployed in teaching-learning situations at different stages of studies. Hence, one needs to examine the essential features from the results of both studies. Nevertheless, there are some general conclusions that can be made.

\subsection{The teachers' perspective revisited}

The presented results using the paradigm model 'drawing on experiences' and the related teaching strategies and activities allow having a closer look at the roles of teachers and their attitudes towards teaching.

The described teaching strategies and activities indicate different roles of teachers. Teachers employ distinct modes of steering within the learning processes when performing these roles: They act as classical lecturers in the sense of experts in their academic or professional field, as moderators and as learning companions or tutors, and as learning facilitators and advisors that support students' self-directed learning. The aforementioned roles are not exclusively bound to specific teaching strategies but instead, different roles can be performed within one single strategy.

Teaching strategies and activities are underpinned by specific attitudes. Through their actions, teachers show an appreciation for the students as holistic persons with manifold experiences from different contexts. This becomes apparent as the teachers ascribe expert knowledge to the students. Thus, they assume that students can provide substantial contributions and that they are willing to learn from each other and not only from the teacher without fundamentally challenging the hierarchical relationship between teachers and students. Teachers show mindfulness in their strategies and activities, for example, when they describe activities to create an atmosphere of trust as a precondition for open discourse and the sharing of experiences. This, again, is a precondition for (mutual) learning. Teachers put their own expert role aside by taking a backseat and promoting the (self-) steering of students. Although there exist 'basic concepts' for teaching activities, teachers show flexibility in need-oriented modification of strategies and actions, and hence situational openness. Finally, a basic understanding of teaching in higher education emerges that supports critical thinking, critical reflection, and personal development of the students and hence, far exceeds mere presentation of knowledge and its application. 


\subsection{The students' perspective revisited}

The results of students' learning and development over the course of studies from their perspective show different developments and different concepts of learning.

With regard to their learning counterparts, it is striking how important fellow students, their experiences and their perspectives become during the course of study. While the acquisition of knowledge and hence the expertise of the teachers is central at the beginning of their studies, in retrospect, teachers are regarded more as individuals from whom valuable learning can be accrued and as supportive partners in students' learning processes who provide encouraging and critical feedback. Hence, students gain autonomy for their own learning and decide what and with whom they learn. They attain the self-assurance needed to expose themselves to new knowledge, and move from simple knowledge acquisition to a more critical involvement with their own (professional) identities.

The approaches to learning change from a more superficial approach to a deeper one. Whereas at the outset, students first try to obtain knowledge and translate it directly into practice, over the course of their studies, they begin questioning their own frames of reference and practices and try to gain more understanding of themselves and their professional fields.

\subsection{Connecting the perspectives}

What can be drawn from the results of these two perspectives for future perspectives on teaching and learning practices? Taking as reference point the changing relationship between teachers and learners and three sets of boundary issues around (1) expertise, (2) communities of learning, and (3) content and communication proposed for digital teaching and learning (Beaty \& Howard, 2010) the two perspectives of the studies can be connected.

Expertise in digital teaching and learning is held by both students and teachers and becomes "a shifting quality dependent on the activity, the roles taken by the participants and technological context within which learning is facilitated" (Beaty \& Howard, 2010, p. 603). As the students' perspective shows, students draw their expertise from different backgrounds, i.e., from their professional vocation, from expertise in the group built on individual experience and the backgrounds of those involved. The teacher "as a fellow holder of expertise" (ibid., p. 605) brings in her academic knowledge and skills. From the teachers' perspective, the central prerequisite of collaboration and co-construction of knowledge based on shared expertise is shown in the teaching strategy 'creating an atmosphere for learning'. Students are invited to share their experiences and their expertise on an equal footing with teachers as experts. Furthermore, in the strategy 'stimulating learning from each other' teachers encourage them to learn from each other and enrich one another through their academic and professional expertise.

The boundaries of communities of learning are called into question as students and teachers are members in different networks, both professionally and academic, formalized and non-formalized, with different forms of engagement (Beaty \& Howard, 2010). According to Wenger-Trayner et al. (2015), in professional occupations, the body of knowledge is best understood as landscapes of practice that consist of different communities of practice. In university continuing education, students move between different landscapes: their professional workplace communities, their academic communities and their work life communities. These transitions pose challenges for them (Fenton-O'Creevy, Brigham, Jones, \& Smith, 2015). The study on students' perspective shows that one central issue over the course of studies for students is translating experiences and learning gained in the professional world into the academic world and the other way around. The teacher's role in this endeavor is shown in the strategy 'stimulating reflection' that encompasses all teaching strategies: they aim to support students to become "reflective learners" (Cendon, 2016) in order to transform their experiences and their learnings for the respective landscapes of practice. Hence, stimulating reflection in different forms is an important prerequisite in allowing students to move successfully between different communities of learning or, more precisely, between landscapes of practice.

In digital teaching and learning, the boundary between communication and content is less defined. Following Beaty and Howard (2010), the teacher becomes "the navigator of the content and the learning process" (p. 605). The results of the study on the students' perspective show that the focus on learning of content as knowledge from the expertise of the teachers is overruled during the course of studies by the focus on feedback and hence communication and dialogue with the teachers. The results of the study on teachers' perspectives show that teachers act as moderators of learning. Thus, content is embedded in the dialogue between teachers and learners, as well as learners and learners, always taking 'drawing on experiences' as a reference point. The art of teaching is shown in the situational variation of teaching actions to connect content with the experience of the students. Therefore, the creation and dissemination of content is not only underpinned by communication, but rather directed by it.

\section{CONCLUSIONS}

Linking the perspectives of students and teachers in university continuing education in this paper shows that the relationships between teachers and students change over the course of study. Hence, different and new ways of understanding of (one's) roles as teacher and for understanding teaching and learning are needed. With a look towards future perspectives of teaching and learning in the era of digitalization, this can take different routes as the results of this paper indicate.

Structure for learning has been an important part on the side of students who have to balance their professional and their student lives for a certain period of time. Hence, structured learning paths over the course of studies supported by digital technologies have proved to be a good way for providing students with an organizational frame in which they could develop as students and gain autonomy in their learning. With focus on the developmental perspective of students' learning, the five stage model of collaborative learning online and the respective competencies of e-moderators as developed by Salmon $(2011,2013)$ can be helpful to design pedagogical models for building up students' autonomy and self-regulated learning.

Second, teachers in higher education with their various approaches matter. As the results show, different roles and different strategies are displayed by experienced teachers and are also needed from students' perspective. It is seldom that all of the strengths are combined in one teacher. Additionally, whereas the integration of teachers from outside higher education helps to connect the professional and academic worlds, teachers bring in specific subject expertise but less often experiences with teaching in higher education. Hence, a differentiation of roles of teachers is needed. Thus, a good presenter of knowledge or a captivating (e-) lecture is as important as a good facilitator or tutor. This differentiation can be used to guide young and less experienced teachers in developing their scholarship of teaching (Biggs \& Tang, 2011) and to guide professionals from outside of academia to find adequate roles of teaching (Cendon \& Flacke, 2013). 
This leads finally to the issue of supporting teachers in pedagogic and technical ways. Within digital learning, this can mean translating concepts for teaching into different modes of delivery, supporting the use of web-based tools, and thus minimizing the technical and administrative effort for teachers. From a future perspective, this can mean thinking about new functions within higher education: Willcox et al. (2016) recommend the profession of the 'learning engineer'. S/he is sketched as a professional who is both a learning designer and an engineer and who connects the worlds of research on learning, technology and teaching and is prepared to work with teachers, administrators and students. This would mean more institutional support and value for teaching in higher education and the support of good teaching practices in lifelong learning programs at universities and beyond.

\section{REFERENCES}

Akbar, M. (2016). Digital Technology Shaping Teaching Practices in Higher Education. Frontiers in ICT, 3. doi:10.3389/fict.2016.00001

Attard, A., Di Ioio, E., Geven, K., \& Santa, R. (2010). Student Centered Learning. An Insight Into Theory And Practice. Bucharest. Retrieved from http://media. ehea.info/file/ESU/07/4/2010-T4SCL_An_Insight_Into_Theory_And_Practice_565074.pdf

Bates, A. W. (2015). Teaching in a Digital Age. Ontario: Tony Bates Associates Ltd. Retrieved from https://opentextbc.ca/teachinginadigitalage/

Beaty, L. \& Howard, J. (2010). Re-Conceptualising the Boundaries of Networked Learning: The Shifting Relationship between Learners and Teachers. In L. Dirckinck-Holmfeld, V. Hodgson, C. Jones, M. de Laat, D. McConnell, \& T. Ryberg (Eds.), Proceedings of the 7th International Conference on Networked Learning 2010 (pp. 593-601). Lancaster: University of Lancaster. Retrieved from http://www.lancaster.ac.uk/fss/organisations/netlc/past/nlc2010/ abstracts/PDFs/Beaty 2.pdf

Biggs, J. \& Tang, C. (2011). Teaching for Quality Learning at University. What the Student Does. (4th edition). Maidenhead: Society for Research into Higher Education \& Open University Press/McGraw Hill.

Cendon, E. (2016). Bridging Theory and Practice. Reflective Learning in Higher Education. In W. Nuninger \& J.-M. Châtelet (Eds.), Handbook of Research on Quality Assurance and Value Management in Higher Education (pp. 304-324). Hershey, PA: IGI Global. Retrieved from doi:10.4018/978-1-52250024-7

Cendon, E. (2017). Reflexion in der Hochschulweiterbildung. Verbindungsglied zwischen unterschiedlichen Erfahrungswelten. Zeitschrift Hochschule und Weiterbildung, 2, 42-47. doi:10.4119/UNIBI/ZHWB-2017-02-52

Cendon, E. (in press). The Reflective Practitioner? Entwicklung und Reflexion aus Sicht von Weiterbildungsstudierenden. In W. Jütte, M. Kondratjuk \& M. Schulze (Eds.), Hochschulweiterbildung als Forschungsfeld. Disziplinäre, theoretische, empirische und methodische Zugänge. Bielefeld: W. Bertelsmann Verlag.

Cendon, E. \& Flacke, L. B. (2013). Praktikerinnen und Praktiker als hochschulexterne Lehrende in der wissenschaftlichen Weiterbildung. Eine notwendige Erweiterung des Lehrkörpers. Hochschule und Weiterbildung, 1, 36-40.

Cendon, E., Mörth, A., \& Schiller, E. (2016). Rollen von Lehrenden. Empirische Befunde. In E. Cendon, A. Mörth, \& A. Pellert (Eds.), Theorie und Praxis verzahnen. Lebenslanges Lernen an Hochschulen (pp. 201-221). Münster: Waxmann.

Cutajar, M. (2016). Qualitative Differences in Students' Perceptions of others in a Networked Learning Environment. In S. Cranmer, N. B. Dohn, M. de Laat, T. Ryberg, \& J.-A. Sime (Eds.), Proceedings of the 10th International Conference on Networked Learning 2016 (pp. 472-480). Lancaster. Retrieved from http://www.networkedlearningconference.org.uk/abstracts/pdf/P53.pdf

Entwistle, N. (2009). Teaching for Understanding at University. Deep Approaches and Distinctive Ways of Thinking. Basingstoke: Palgrave Macmillan. doi:10.1007/978-1-137-09106-2

Fenton-O'Creevy, M., Brigham, L., Jones, S., \& Smith, A. (2015). Tourists and sojourners in practice-based education. In E. Wenger-Trayner, M. Fenton-O'Creevy, S. Hutchinson, C. Kubiak, \& B. Wenger-Trayner (Eds.), Learning in Landscapes of Practice: Boundaries, Identity, and Knowledgeability in Practice-based Learning (pp. 43-63). London/New York: Routledge.

Kember, D. (1997). A Reconceptualisation of the Research into University Academics' Conceptions of Teaching. Learning and Instruction, 7(3), 255-275. doi:10.1016/S0959-4752(96)00028-X

Knowles, M. S. (1975). Self-Directed Learning. New York: Association Press.

Marton, F., Beaty, E., \& Dall'Alba, G. (1993). Conceptions of Learning. International Journal of Educational Research, 19(3), 277-300.
Mayring, P. (2000). Qualitative Content Analysis. Forum Qualitative Sozialforschung / Forum: Qualitative Social Research, 1(2), Art. 20. doi:10.17169/ fqs-1.2.1089

Redecker, C., Leis, M., Leendertse, M., Punie, Y., Gijsbers, G., Kirschner, P., Stoyanov, S., \& Hoogveld, B. (2011). The Future of Learning: Preparing for Change. Luxembourg: Publications Office of the European Union. Retrieved from http://dx.publications.europa.eu/10.2791/64117

Roberts, G. (2004). Teaching using the Web: Conceptions and Approaches from a Phenomenographic Perspective. In P. Goodyear, S. Banks, V. Hodgson, \& D. McConnell (Eds.), Advances in research on networked learning (pp. 221244). Boston: Kluwer Academic Publishers. doi:10.1007/1-4020-7909-5_10

Ryberg, T. (2013). Designing Problem-based Learning in Virtual Learning Environments - Positioning Teachers as Competent Practitioners and Designers. In E. Christiansen, L. Kuure, A. Mørch, \& B. Lindström (Eds.), Problem-based learning for the 21st century: new practices and learning environments (pp. 101-128). Aalborg: Aalborg University Press.

Salmon, G. (2011). E-Moderating: The Key to Online Teaching and Learning (3rd ed). New York: Routledge.

Salmon, G. (2013). E-tivities: The Key to Active Online Learning (Second edition). New York: Routledge, Taylor \& Francis Group.

Schuetze, H. G. (2014). From Adults to Non-Traditional Students to Lifelong Learners in Higher Education: Changing Contexts and Perspectives. Journal of Adult and Continuing Education, 20(2), 37-55. doi:10.7227/JACE.20.2.4

Schuetze, H. G. \& Slowey, M. (Eds.). (2012). Global Perspectives on Higher Education and Lifelong Learners. New York: Routledge.

Strauss, A. L. \& Corbin, J. M. (1990). Basics of Qualitative Research. Grounded Theory Procedures and Techniques (2nd printing). Newbury Park, CA: Sage.

Sursock, A. (2015). Trends 2015: Learning and Teaching in European Universities. Brussels: European University Association. Retrieved from http://www.eua. be/Libraries/publications-homepage-list/EUA_Trends_2015_web

Trigwell, K., Prosser, M., \& Waterhouse, F. (1999). Relations between teachers' approaches to teaching and students' approaches to learning. Higher Education, 37(1), 57-70. https://doi.org/10.1023/A:1003548313194

Wenger-Trayner, E., Fenton-O'Creevy, M., Hutchinson, S., Kubiak, C., \& WengerTrayner, B. (Eds.). (2015). Learning in Landscapes of Practice: Boundaries, Identity, and Knowledgeability in Practice-based Learning. London; New York: Routledge.

Willcox, K. E., Sarma, S., \& Lippel, P. H. (2016). Online Education: A Catalyst for Higher Education Reforms (Final Report). Cambridge: MIT. Retrieved from https://oepi.mit.edu/files/2016/09/MIT-Online-Education-Policy-Initiative-April-2016.pdf

Zuber-Skerritt, O. \& Cendon, E. (2014). Critical Reflection on Professional Development in the Social Sciences. Interview Results. International Journal for Researcher Development, 5(1), 16-32. doi:10.1108/IJRD-11-2013-001

How to cite this article: Cendon, E. (2018). Lifelong Learning at Universities: Future Perspectives for Teaching and Learning. Journal of New Approaches in Educational Research, 7(2), PP. 81-87. doi: 10.7821/naer.2018.7.320 